the University during October 1951-May 1952. The meetings will consist of lectures and discussions on topics on which research is being carried out at the University, and the object of the series is to facilitate co-operation between the University and industry. The subjects, which will be discussed on consecutive Wednesday afternoons (2.30-4.30 p.m.) between the dates as shown, are as follows: dynamic properties of metals (October 17-31), fatigue of metals (November 21-December 1;), structural analysis and the use of models (January 16-30), use of analogies in fluid mechanics (February 13-20), photoelasticity (March 5-19), and dynamic properties of rubber (April 23-May 7). Admission to the meetings is free. Enrolment forms and further details can be obtained from the Registrar of the University, University Park, Nottingham.

\section{Use of Solid Carbon Dioxide in preparing a Cold} Bath

L. G. E. BELL, Department of Zoology, King's College, Strand, London, W.C.2, writes: "Making up a cooling bath by adding solid carbon dioxide to industrial methylated spirit often involves considerable frothing of the spirit unless the addition is made very slowly. I have found that a few drops of a light paraffin sprinkled on the surface of such a bath reduces this frothing very considerably. Three or four drops of cigarette-lighter fuel are sufficient to control a surface of thirty inches square and enable a rapid addition of solid carbon dioxide to be made."

\section{Announcements}

WiтH the retirement of Prof. H. Hartridge in May last, the Vision Research Unit of the Medical Research Council has been re-formed as the Group for Research in the Physiology of Vision, under the directorship of Dr. L. C. Thomson. The scope of the work undertaken by the members of the new Group is essentially similar to that of the Vision Research Unit, and the address remains the same, namely, Institute of Ophthalmology (University of London), Judd Street, London, W.C.1.

THE Royal Society of Arts has awarded the R. B. Bennett Empire Prize for 1951 to Mr. E. Bruce Levy, director of the Grasslands Research Division of the New Zealand Department of Scientific and Industrial Research, for his work on grassland farming. This Prize, which is worth 100 guineas, was endowed in 1944 by the late Lord Bennett and is awarded every three years for the most outstanding contribution from the Dominions and Colonies of the British Commonwealth to the promotion of the arts, agriculture, industries or commerce.

Prof. N. F. Astrury, professor of applied physics in the New South Wales University of Technology, l:as been appointed to the chair of physics at the Gordon Memorial College, Khartoum.

TrE National Conference of the Institute of Personnel Management, which includes the annual general meeting of the Institute, will be held at the Royal Hotel, Harrogate, during October 5-7, the theme being "Personnel Management and Pro. ductivity". The Conference will begin at 8.30 p.m. on October 5, and prior to this on the same day a one-day course on "Personnel Management" will be r.eld in the Lounge Hall, Royal Baths, Harrogate. Further details of both meetings can be obtained from the Institute at Management House, Hill Street, London, W.1.
A SYMPOSIUM on the corrosion of buried metals, organized by the Iron and Steel Institute in con. junction with the British Iron and Steel Research Association and the Corrosion Group of the Society of Chemical Industry, will be held at the offices of the Iron and Steel Institute, at 4 Grosvenor Gardens, London, S.W.1, during December 12, with Sir Charles Goodeve, director of the British Iron and Steel Research Association, in the chair. The symposium will be open to all, free of charge. Admission tickets (application to be made before October 13) and further details can be obtained from the secretary of the Institute at the above address.

A SECOND conference on coastal engineering, sponsored by the Southwest Research Institute, San Antonio, Texas, in co-operation with the University of California, Texas A. and M. Research Foundation, Rice Institute, University of Houston and the American Society of Civil Engineers (Houston Branch), will be held at the Rice Hotel, Houston, Texas, during November 7-10. The major topics to be discussed will be the fundamentals of wave action, development of basic design data, natural and artificial movement of sediment, site criteria for harbours and other coastal works, design and construction of structures exposed to wave action, and the biological impact of marine structures. Further information can be obtained from the conference secretary, Charles E. Balleisen, c/o Southwest Research Institute, 8500 Culebra Road, San Antonio 6 , Texas.

THE Chemical-Biological Coordination Center of the National Research Council is organizing the second Symposium on Chemical-Biological Correla. tion, to be held at the National Academy of Sciences in Washington, D.C., during October 24-25, 1952, and it is intended to include in the programme one or several scientific films which deal specifically with the effect of ehemicals upon biological systems, such as organisms, organs, tissues, cells, etc. Any information about the availability of such films should be sent to the Center at 2101 Constitution Avenue, Washington, D.C.

THE second International Congress of Biochemistry will be held in Paris during July 21-27, 1952. The programme has been provisionally arranged in seven sections, as follows: biochemistry of steroids, biochemistry of hæmatopoiesis, biogenesis of proteins, tricarboxylic acid cycles, bacterial metabolism, mechanism of action of antibiotics, protein hormones and hormones derived from proteins. Communications dealing with other biochemical problems will be grouped together in further appropriate sections. Those intending to read papers should send in the titles before March 1, 1952, and a summary of less than two hundred words before April 1, 1952, to the general secretary of the Congress, Prof. J. E. Courtois, 4 Avenue de l'Observatoire, Paris 6e.

The Board of Greenkeeping Research has recently been registered as a public company limited by guarantee under the provisions of the Companies Act, 1948, and will henceforth be known as the Sports Turf Research Institute. The new Institute remains as previously a non-commercial, non-profitmaking organization and will maintain the work of the old Board as a research, advisory and educational body in problems of turf (see Nature, 166, $22 ; 1950$ ). The headquarters will continue to be at the St. Ives Research Station, Bingley, Yorkshire. 